\title{
Productive Performance, Feed Utilization Efficiency and Blood Profile of Male Zaraibi Goats Fed Rations Containing Sesame Seeds Unsuitable for Manufacturing As An Inexpensive and Untraditional Source of Protein. El-Emam, G. I.; G.A. Maged; W.M.A. Sadek; A. M. Abdel-Gawad; M.E. Ahmed and K. Hussein Animal Prod. Res. Inst., Agric. Res. Center, Dokki, Giza, Egypt.
}

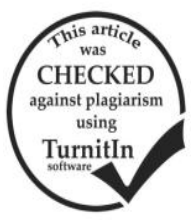

\section{ABSTRACT}

This research work was carried out to investigate the effect of using Sesame seeds in goats rations on some rumen parameters, blood profile, feed utilization and growth performance of Zaraibi kids. Fifteen Zaraibi kids ( $17.53 \pm 0.24 \mathrm{~kg}$ live weight and 5 months old) were divided into 3 groups ( 5 kids each). The control group (G1) was fed a ration consisting of concentrate feed mixture (CFM) and corn silage (CS) according to NRC (1981) recommendation. Sesame seeds (SS) were used to replace 10 and $20 \%$ of total CP of rations for groups G2 and G3, respectively. The feeding trail lasted for 15 weeks. The obtained results showed that the daily DM intake tended to decrease $\left(71.69,67.24\right.$ and $\left.68.01 \mathrm{~g} / \mathrm{kg} \mathrm{w}^{0.75}\right)$ as a result to substitution of CFM with SS in goat's rations (G1, G2 and G3, respectively). In the same time, the daily water consumption as $\mathrm{ml} / \mathrm{g} / \mathrm{DM}$ intake was slightly higher with increasing level of SS in the rations. Concerning ruminal parameters, the effect of the experimental rations on ruminal $\mathrm{pH}$ values and ammonia-N concentration were not significant. But, ruminal total VFA's during 3 and $6 \mathrm{hrs}$ post-feeding were significant as higher $(\mathrm{P}<0.05)$ with $\mathrm{G} 2$ and $\mathrm{G} 3$, compared with $\mathrm{G} 1$. The obtained results indicated also that most tested blood profile parameters were not significantly affected by tested experimental rations. Daily body gain (DBG) recorded the highest value (76.67 g) with G2 followed by G3 (72.62 g) and lastly G1 (65.00 g) and the differences were significant. The DBG increased by 17.95 and $11.72 \%$ with G2 and G3, respectively compared with control groups (G1). The best feed utilization efficiency based on DM was recorded with G2 (8.67) followed by G3 (9.01) in comparison with G1 (10.40). Moreover, the improvement in feed efficiency, based on CP, was 15.20 and $10.40 \%$ with two tested groups (G2 and G3, respectively) compared with control (G1). Thus, the feed economic efficiency was noticeably better (by $24.07 \%$ ) as a result to using of SS at two tested levels 10 and $20 \%$ compared with control group.

Keywords: Sesame seeds- Zaraibi goats- growth performance- feed economic efficiency

\section{INTRODUCTION}

Nutrition is a major factor affecting the physiological and metabolic status of from animals. In Egypt, there is a wide gap between the available feedstuffs and farm animals requirements. During summer season, green forages with reasonable protein content are not adequately available. According, there is a clear drop in productive performance of different farm animals. Many attempts were carried out to introduce some green forages or seeds containing higher protein content such as Sesbania sesban and Erythria indica (Soliman et al., 1997 and Pugalenthi et al., 2004). Legume seeds are valuable sources of protein, oil, carbohydrates, minerals and vitamins. They are playing an important role in human nutrition mainly in developing countries (Mohamed and Rangappa, 1992 and Yanez et al., 1995). Sesame (Sesamum indicum L.) seed is a drought-tolerant crop adapted to many soil types (Ram et al., 1990). Full-fat Sesame seed and the meal after oil extraction are not only excellent sources of edible nutrients (45 to $50 \%$ lipid, 15 to $20 \%$ protein and 10 to $15 \%$ carbohydrate (Lee et al., 2005). The amino acid composition of protein is similar to that soybean meal with the exception of low lysine (Mamputu and Buhr, 1991) and higher methionine in Sesame (Dipasa, 2003). The fiber content of the seed ranges from 2.7 to $6.7 \%$ (Beckstrom-Sternberg and Duke, 1994). Nzikou et al. (2009) studied the quantitative evaluation of the nutritional constituents of the nutritional constituents of Sesame seeds such as protein, energy and minerals and they reported that Sesame seeds is a good source rich in all the essential nutrients needed by the live stocks. Literature on using Sesame seeds (SS) in feeding Zaraibi goats is scarce.
Therefore, the aim of this work was to investigate the effect of feeding Sesame seeds as a source of protein to partly replace the expensive $\mathrm{CP}$ of the concentrate feed mixture on feed utilization and economical efficiency as well as growth performance. Some metabolic parameters (rumen and blood) were also studied.

\section{MATERIALS AND METHODS}

This study was conducted at the Animal Production Research Station, El-Serw, belonging to Animal Production Research Institute, Agricultural Research Center, Egypt.

\section{Animals and feeding :}

Fifteen growing Zaraibi kids, selected from ElSerw Station Herd, with an average age of 5 months and $17.53 \pm 0.24 \mathrm{~kg}$ weight were used. The animals were divided according to their body weight into 3 similar groups (5 each) to study the effect of using Sesame seeds (SS) as a source of protein in goat's diets at levels, of 0 (G1), 10\% ( G2) and 20\% ( G3) of total crude protein of rations. Each group was housed in a semi-roofed yard. The animals were weighed at the beginning then biweekly. Zaraibi kids were fed for 3 weeks as a transitional period on the same experimental rations before the start of the experimental work. Feeding the experimental rations lasted for 15 weeks. The nutrient requirements were calculated according to NRC (1981) of goats. The concentrate (CFM) and roughage (corn silage) were offered at 60:40 ratio as reported by Tawfik et al. (2005) and Soliman et al. (2010) on growing lambs and Zaraibi kids, respectively. Animals were fed mixed rations in groups. The CFM consisted of $26 \%$ undecortecated cotton meal, 40 
$\%$ yellow corn, $27 \%$ wheat bran, $3.5 \%$ molasses, $2 \%$ limestone, $1 \%$ common salt and $0.5 \%$ minerals mixture. The chemical composition of the tested ingredients was determined (Table 1). Water was available at all times and was measured as average for each group (per $\mathrm{ml} / \mathrm{h} / \mathrm{l}$ ). Diets were offered twice daily at 8.0 am and $3.0 \mathrm{pm}$ any refused were daily recorded. Proximate chemical analysis of the feeds was carried out according to A.O.A.C. (1995).

Rumen samples:

Rumen fluid samples were taken from 3 animals of each experimental group using stomach tube before feeding ( 0 time) and at 3 and 6 hrs postfeeding at the end of growin $g$ period. The samples were filtered through 3 layers of gauze and immediately subjected to the determination of $\mathrm{pH}$ value by $\mathrm{pH}$ meter. Ammonia nitrogen $(\mathrm{NH} 3-\mathrm{N})$ concentration was measured according to the method of Conway (1957), Microbial protein was determined according to Schultz and Schultz (1970), whereas total volatile fatty acids (VFA's) was determined according to the technique described by Warner (1964).

\section{Blood samples:}

Blood samples were collected from the jugular vein once before feeding ( 3 animals in each) at the end of growing period. Blood samples were centrifuged at $4000 \mathrm{rpm}$ for $20 \mathrm{~min}$. Part of the separated serum was directed to enzymes activity determination, while the other part was stored frozen at-20 0c till the biochemical analysis. Commercial kits were used for colorimetric biochemical determinations.

\section{Economic efficiency :}

Economic efficiency was calculated as total output/ total input according to the local prices ( where 1 ton of CFM cost 2550LE, CS cost 300 LE and 1 ton Sesame seeds coat $1800 \mathrm{LE}$ while1 $\mathrm{kg}$ live body weight of male Zaraibi goats for 35LE).

\section{Statistical analysis:}

Data were statistically analyzed using One-Way Layout with Means Comparisons Procedure SAS (2003). Significant differences among means were evaluated using Duncan's Multiple Range Test of SAS (2003). The model used for the analysis of all parameters was:

$$
\begin{aligned}
& \qquad \mathbf{Y i j}=\boldsymbol{\mu}+\mathbf{T i}+\mathbf{e i j} \\
& \text { Where: } \mu \text { is the overall mean } \\
& \text { Ti is the treatment type } \\
& \text { eij is the random error term }
\end{aligned}
$$

\section{RESULTS AND DISCUSSION}

\section{Chemical composition :}

The chemical analysis as shown in Table 1 indicated that Sesame seeds (SS) contained 17.0\% CP, $45.70 \%$ EE, 52.63\% NFE, 5.90\% CF and $4.50 \%$ Ash. Similar results were reported by Lee et al., 2005, Beckstrom-Sternberg and Duke, 1994, Kaneko et al., 2002 and El- Saidy et al., 2009. In this respect, Nzikou et al. (2009) reported that the Sesame seeds contained 5.7\% moisture, $20 \% \mathrm{CP}, 3.70 \%$ Ash, $3.2 \mathrm{CF}, 54.0 \%$ fat and 13.4 carbohydrate, in addition, the seeds were found to be

\begin{tabular}{|c|c|c|c|c|c|c|c|}
\hline \multirow{2}{*}{ Feed } & \multirow{2}{*}{ DM } & \multicolumn{6}{|c|}{ On DM basis } \\
\hline & & OM & $\mathbf{C F}$ & $\mathbf{C P}$ & $\mathbf{E E}$ & NFE & Ash \\
\hline Concentrate feed mixture, CFM & 91.30 & 94.17 & 15.50 & 14.00 & 3.33 & 61.34 & 5.83 \\
\hline Sesame seeds, SS & 94.50 & 95.50 & 5.90 & 17.00 & 45.70 & 26.90 & 4.50 \\
\hline Corn silage, $\mathrm{CS}$ & 30.00 & 90.90 & 29.10 & 9.00 & 3.09 & 49.71 & 9.10 \\
\hline
\end{tabular}
good source of minerals such as potassium, phosphorus, magnesium, calcium and sodium.

Table (1): proximate chemical analysis of feed ingredients.

\section{Daily feed intake and water consumption:}

The average daily DM intake of Zaraibi kids is summarized in Table 2. The total DM intake as $\mathrm{g} / \mathrm{h}$ tended to decrease $(676,665$ and $654.3 \mathrm{~g})$ with increasing level of Sesame seeds $(0,10$ and 20\% ) in rations of Zaraibi kids. The corresponding values of intake when related to metabolic body size were 71.69 , 67.24 and $68.01 \mathrm{~g} / \mathrm{h} \mathrm{kgw}^{0.75}$, respectively.

Table (2): Average daily feed intake and water consumption of Zaraibi kids fed the experimental rations.

\begin{tabular}{lccc}
\hline Item & G1 & Groups & G2 \\
\hline Daily DM intake, g/h: & & 348 & 290 \\
CFM & 405 & 47.7 & 95.3 \\
SS & -- & 269.3 & 269.0 \\
CS & 271.0 & 665 & 654.3 \\
Total DM intake & 676 & 3.13 & 3.20 \\
DM intake, \%BW & 3.39 & 67.24 & 68.01 \\
DM intake, g/kgw 0.75 & 71.69 & $40: 60$ & $41: 59$ \\
Roughage: Concentrate (R/C) ratio & $40: 60$ & & \\
Water consumption: & & 2.13 & 2.05 \\
L/h/d & 2.21 & 100 & 100 \\
ml/kg BW & 111 & 215 & 213 \\
ml/kg w 0.75 & 234 & 3.20 & 3.13 \\
ml/g DM intake & 3.27 & & \\
\hline
\end{tabular}


The same trend was observed also with daily intake as \% BW among the experimental treatments as shown in Table 2. This decrease in DM intake with increasing level of SS could be attributed to the crude protein content in SS which was higher than CFM ( 17.0 vs $14.0 \%$ ) as shown in Table 1 . The obtained values of daily feed intake are within the normal range given by Ahmed et al. (2000) for Zaraibi kids fed restricted 100\% high concentrate ( ranged from 623.1 to $668.9 \mathrm{~g} / \mathrm{h}$ ). Also, El-Kholany et al. (2013) found that the daily DM intake when related to body weight (\% B W) ranged from 3.19 to 3.39 in male Zaraibi goats fed diets containing Sesbania seeds as a source of protein.

Concerning water consumption, the obtained data indicated that the differences in water consumption as $\mathrm{L} /$ head and $\mathrm{ml} \mathrm{/} \mathrm{kg} \mathrm{w} 0.75$ tended to decrease with increasing level of SS as shown in Table 2. Similarly, the values of daily water consumption was lower ( $3.27,3.20$ and $3.13 \mathrm{ml} / \mathrm{g} \mathrm{DM}$ intake) with increasing level of SS in goat rations $(0,10$ and $20 \%$, respectively). The values of water consumption in this study are nearly similar to those obtained by Ahmed et al., (2009) on growing Rahmani lambs ( ranged from 1.90 to $3.16 \mathrm{ml} / \mathrm{g}$ DM intake) and Soliman et al., (2010) on growing Zaraibi kids (ranged from 2.22 to $3.30 \mathrm{ml} / \mathrm{g} \mathrm{DM}$ intake).

\section{Ruminal parameters:}

Results of $\mathrm{pH}$ values (Table, 3) indicated that maximum $\mathrm{pH}$ values were recorded at 0 time with all groups without significant differences among treatments and then gradually decreased to the minimum values at 3 hrs. post feeding and tended to increase again thereafter at 6 hrs. post feeding with all groups. Similar trend was found by Ibrahim et al. (2012) and El-Sayed and Sadek (2015) with growing lambs and Zaraibi kids, respectively.
At the same time, ruminal ammonia-N concentration was greatly higher post-feeding than before feeding and that maximum values of $\mathrm{NH} 3-\mathrm{N}$ in the rumen were reached at $3 \mathrm{hrs}$. post-feeding then decreased with all groups without noticeable differences among tested experimental groups. Similar results were observed by El-Kholany et al., (2013) with using Sesbania seeds in goat's rations.

The obtained results indicated that microbial proteins content during 3 and 6 hrs. Post-feeding was significantly higher $(\mathrm{p}<0.05)$ with G2 ( 0.582 and 0.508 $\mathrm{g} / 100 \mathrm{ml}$, respectively) compared with G1 (0.560 and 0.485 $\mathrm{g} / 100 \mathrm{ml}$, respectively), whereas G3 recorded medium values as shown in Table 3. Generally, the highest values of microbial protein $(0.392,0.582$ and $0.508 \mathrm{~g} / 100 \mathrm{ml})$ and lowest values of ruminal ammonia-N concentration ( 16.20, 23.18 and $22.10 \mathrm{~g} / 100 \mathrm{ml})$ were recorded with $\mathrm{G} 2$ at all times ( 0,3 and 6 hrs., respectively).

Concerning total VFA,s concentration, it could be noticed that ruminal total VFA,s concentration at 3 and 6hrs. post-feeding were significantly lower with control ration (G1) than those of two tested rations with no significant differences among them. These results may be possibly related to the high gross energy content of the Sesame seeds as reported by Lee et al. (2005) and ElSaidy et al., (2009).

Generally, the highest value of total VFA,s concentration was recorded at $3 \mathrm{hrs}$. post-feeding which was reflected on lowering $\mathrm{pH}$ values ( Table, 3 ) at that time as reported by Ahmed et al. (2013) and Mehrez et al. (2013) with female and male Zaraibi goats, respectively. The obtained data of rumen parameters are within the normal range reported by Ahmed and ElKholany (2012), El-Sayed and Sadik (2015) Gabr et al. (2015) with small ruminants ( sheep and goats).

Table (3): Some rumen liquor parameters of male Zaraibi goats fed the experimental rations.

\begin{tabular}{lcccc}
\hline Item & Hours & G1 & G2 & G3 \\
\hline \multirow{2}{*}{ pH value } & 0 & $6.90 \pm 0.10$ & $6.93 \pm 0.17$ & $6.98 \pm 0.12$ \\
& 3 & $6.57 \pm 0.09$ & $6.48 \pm 0.04$ & $6.52 \pm 0.04$ \\
& 6 & $6.70 \pm 0.06$ & $6.58 \pm 0.04$ & $6.62 \pm 0.04$ \\
Ammonia-N (mg/100ml) & 0 & $16.33 \pm 0.61$ & $16.20 \pm 0.53$ & $17.57 \pm 0.47$ \\
& 3 & $23.20 \pm 0.55$ & $23.18 \pm 0.53$ & $24.20 \pm 0.46$ \\
Microbial protein (g/100ml) & 6 & $22.60 \pm 0.64$ & $22.10 \pm 0.44$ & $23.37 \pm 0.98$ \\
& 0 & $0.337 \pm 0.006$ & $0.342 \pm 0.003$ & $0.340 \pm 0.01$ \\
Total volatile fatty acids (mEq/100m) & 3 & $0.560 \pm 0.008^{\mathrm{b}}$ & $0.582 \pm 0.01^{\mathrm{a}}$ & $0.572 \pm 0.008^{\mathrm{ab}}$ \\
& 6 & $0.485 \pm 0.007^{\mathrm{b}}$ & $0.508 \pm 0.008^{\mathrm{a}}$ & $0.503 \pm 0.007^{\mathrm{ab}}$ \\
& 0 & $8.80 \pm 0.25$ & $9.00 \pm 0.29$ & $9.10 \pm 0.31$ \\
& 3 & $10.10 \pm 0.10^{\mathrm{b}}$ & $10.97 \pm 0.18^{\mathrm{a}}$ & $11.23 \pm 0.15^{\mathrm{a}}$ \\
\hline
\end{tabular}

a-b: Means in the same row with different superscripts differ significantly at $P<0.05$.

\section{Blood profile:}

The effect of the tested experimental rations on most blood parameters was not significant as shown in Table 4. At the same time, the values of $\mathrm{Hb}$ and $\mathrm{RBC}, \mathrm{s}$ were increased with using of SS in goat's rations. Regarding the concentrations of total protein, albumin, globulin, creatinine, urea, uric acid and HDL they were statistically non-significant. But, the concentration of glucose, cholesterol, LDL and activity of AST were increased with increasing level of SS and the differences were significant in serum glucose, cholesterol and LDL only.
These results may be possibly related to the high gross energy content of the Sesame seeds. In the same line, the highest values $(\mathrm{P}<0.05)$ of triglyceride and activity of ALT were recorded with $\mathrm{G} 3$.

Generally the obtainedidata showed that mostiserum parametersiwere slightly differediamong the testedigroups, though some differencesiwere significantibut, all values wereiwithin the normalirange as reported byiKaneko (1989), Ahmed (1999), Ahmediet al, (2009), Sadek (2010), Amr et al. (2014) and Gabr et al. (2015) withiboth sheepiand goats. 
Table (4): Blood profile of male Zaraibi goats as affected by different experimental rations.

\begin{tabular}{lccc}
\hline Item & G1 & G2 & G3 \\
\hline Hemoglobin (Hb), g/dl & $11.03 \pm 0.15^{\mathrm{b}}$ & $11.77 \pm 0.15^{\mathrm{a}}$ & $11.30 \pm 0.10^{\mathrm{b}}$ \\
RBC's, $10^{6} / \mathrm{ul}$ & $12.67 \pm 0.17^{\mathrm{b}}$ & $13.63 \pm 0.19^{\mathrm{a}}$ & $13.00 \pm 0.25^{\mathrm{ab}}$ \\
Total Protein, g/dl & $9.33 \pm 0.66$ & $8.27 \pm 0.13$ & $8.77 \pm 0.23$ \\
Albumin (A), g/dl & $4.07 \pm 0.18$ & $4.03 \pm 0.24$ & $4.07 \pm 0.12$ \\
Globulin (G), g/dl & $5.27 \pm 0.49$ & $4.23 \pm 0.18$ & $4.80 \pm 0.25$ \\
A/G ratio & $0.78 \pm 0.04$ & $0.96 \pm 0.10$ & $0.85 \pm 0.07$ \\
Creatinine, mg/dl & $1.13 \pm 0.09$ & $1.03 \pm 0.07$ & $0.97 \pm 0.03$ \\
Urea, mg/dl & $26.67 \pm 1.45$ & $28.00 \pm 3.51$ & $33.67 \pm 2.03$ \\
Uric Acid & $7.37 \pm 0.43^{\mathrm{b}}$ & $7.87 \pm 0.12 \mathrm{a}^{\mathrm{b}}$ & $8.47 \pm 0.29^{\mathrm{a}}$ \\
Glucose, mg/dl & $57.50 \pm 0.15^{\mathrm{c}}$ & $58.30 \pm 0.21^{\mathrm{b}}$ & $61.20 \pm 0.06^{\mathrm{a}}$ \\
Cholesterol, mg/dl & $82.50 \pm 1.44^{\mathrm{b}}$ & $103.50 \pm 7.79^{\mathrm{b}}$ & $132.50 \pm 10.10^{\mathrm{a}}$ \\
Triglyceride, mg/dl & $54.00 \pm 3.46^{\mathrm{b}}$ & $42.50 \pm 4.33^{\mathrm{b}}$ & $90.00 \pm 2.89^{\mathrm{a}}$ \\
HDL Cholesterol, mg/dl & $23.00 \pm 1.15$ & $21.00 \pm 0.58$ & $21.00 \pm 1.15$ \\
LDL Cholesterol, mg/dl & $48.70 \pm 1.91^{\mathrm{b}}$ & $74.00 \pm 8.08^{\mathrm{ab}}$ & $93.50 \pm 10.68^{\mathrm{a}}$ \\
Cholesterol /HDL & $3.63 \pm 0.25^{\mathrm{b}}$ & $4.91 \pm 0.24^{\mathrm{ab}}$ & $6.45 \pm 0.83^{\mathrm{a}}$ \\
LDL/HDL & $2.15 \pm 0.19^{\mathrm{b}}$ & $3.50 \pm 0.29^{\mathrm{ab}}$ & $4.58 \pm 0.76^{\mathrm{a}}$ \\
AST, ul & $147.50 \pm 1.44$ & $157.50 \pm 1.44$ & $150.00 \pm 5.77$ \\
ALT, ul & $66.00 \pm 0.58^{\mathrm{ab}}$ & $60.00 \pm 5.77^{\mathrm{b}}$ & $72.50 \pm 0.87^{\mathrm{a}}$ \\
AST/ALT & $2.24 \pm 0.00^{\mathrm{ab}}$ & $2.71 \pm 0.29^{\mathrm{a}}$ & $2.07 \pm 0.05^{\mathrm{b}}$ \\
\hline
\end{tabular}

a-c: Means in the same row with different superscripts differ significantly at $P<0.05$.

\section{Growth performance:}

Performances of growing Zaraibi kids in relation to different feeding schemes are presented in Table 5. The obtained data showed that rthe final weight of growing Zaraibi kids was better as a result to using of SS in two tested groups (24.44 and $23.50 \mathrm{~kg}$ for G2 and G3, respectively) compared with control group (22.66 kg). Daily body gain (DBG) recorded the highest values (76.67g) with G2 followed by G3 (72.62 g) and lastly G1 $(65.00 \mathrm{~g})$ and the differences were significant. The positive effects of two SS rations especially G2 on growth performance may be due to the improve in metabolic parameters (rumen and blood) as reported earlier.

\section{Feed utilization:}

Feed conversion of the experimental rations is showed in Table 6 . The best feed conversion (the lowest values) as $\mathrm{kg}$ DM intake/ $\mathrm{kg}$ gain was recorded with $\mathrm{G} 2$ (8.69) followed by G3 (9.01). The bad conversion was recorded with G1 (10.40). The improvement in feed utilization efficiency with using SS at levels 10 and 20\% were 16.63 and $13.37 \%$, respectively comparing with the control group. Similarly, the values of feed conversion expressed as $\mathrm{CP}$ intake/ $\mathrm{kg}$ gain was better in kids received Sesame diets ( 1.06 and 1.12 for G2 and G3, respectively) compared with control $(\mathrm{G} 1,1.25)$. Thus, the feed efficiency calculated as crude protein $/ \mathrm{kg}$ gain were better in G2 and G3 compared with the control (G1) being 15.20 and $10.40 \%$, higher than the control, respectively.

Table (5): Growth performance of Zaraibi kids fed the experimental rations.

\begin{tabular}{lccc}
\hline Item & G1 & G2 & G3 \\
\hline No. of kids & 5 & 5 & 5 \\
Feeding periods, weeks & 12 & 12 & 12 \\
Initial weight, kg & $17.20 \pm 0.58$ & $18.00 \pm 0.77$ & $17.40 \pm 0.51$ \\
Final weight, $\mathrm{kg}$ & $22.66 \pm 0.52$ & $24.44 \pm 0.66$ & $23.50 \pm 0.64$ \\
Total body gain, $\mathrm{kg}$ & $5.46 \pm 0.24^{\mathrm{b}}$ & $6.44 \pm 0.48^{\mathrm{a}}$ & $6.10 \pm 0.31^{\mathrm{ab}}$ \\
Daily body gain, g & $65.00 \pm 2.83^{\mathrm{b}}$ & $76.67 \pm 2.15^{\mathrm{a}}$ & $72.62 \pm 3.75^{\mathrm{ab}}$ \\
\hline
\end{tabular}

a-b: Means in the same row with different superscripts differ significantly at $P<0.05$.

Table (6): feed utilization efficiency by Zaraibi kids as affected by the experimental rations.

\begin{tabular}{|c|c|c|c|}
\hline Item & G1 & G2 & G3 \\
\hline No. of kids & 5 & 5 & 5 \\
\hline Average body weight, kg & 19.93 & 21.22 & 20.45 \\
\hline Metabolic body size, $w^{0.75}$ & 9.43 & 9.89 & 9.62 \\
\hline \multicolumn{4}{|c|}{ Average feed intake*during the experimental period, $\mathrm{g} / \mathrm{h} / \mathrm{d}$} \\
\hline CFM & 405 & 348 & 290 \\
\hline SS & -- & 47.7 & 95.3 \\
\hline $\mathrm{CS}$ & 271.0 & 269.3 & 269.0 \\
\hline Total DM intake & 676 & 665 & 654.3 \\
\hline DM intake, $\mathrm{g} / \mathrm{kgw}^{0.75}$ & 71.69 & 67.24 & 68.01 \\
\hline $\mathrm{CP}$ intake, $\mathrm{g} / \mathrm{h}$ & 81.09 & 81.07 & 81.01 \\
\hline $\mathrm{CP}$ intake, $\mathrm{g} / \mathrm{kgw}^{0.75}$ & 8.60 & 8.20 & 8.42 \\
\hline \multicolumn{4}{|l|}{ Feed conversion: } \\
\hline $\mathrm{Kg} \mathrm{DM} / \mathrm{kg}$ gain & 10.40 & 8.67 & 9.01 \\
\hline $\mathrm{Kg} \mathrm{CP} / \mathrm{kg}$ gain & 1.25 & 1.06 & 1.12 \\
\hline
\end{tabular}

*Group feeding. 
Generally, the obtained values of feed utilization are within the normal range given by Soliman et al. (1997), Ahmed et al. (2000) and Ahmed (2003) for male goats during growing period. In a recent study, Gabr et al. (2015) found that the feed efficiency of growing Zaraibi kids ranged from 8.51 to $9.4 \mathrm{~kg}$ DM intake / $\mathrm{kg}$ gain.

Economic efficiency:

Economic efficiency, estimated as price of gained weight divided by cost of feed consumed for that gain, is presented in Table, 7. The economic efficiency of feeding Zaraibi kids on different experimental rations is shown reduction in feeding cost $(1.4031,1.3318$,
1.2615L.E) with increasing level of Sesame seeds (0, 10 and $20 \%$ ) in the rations (G1, G2 andG3, respectively) Also, using Sesame seeds in goats rations reduced feed cost $/ \mathrm{kg}$ gain to 17.37 L.E for both G2 and G3 compared with value of 21.59 L.E for control (G1). Thus, the economic efficiency was noticeably better $(1.62,2.01$ and 2.01) as a result to using of Sesame seeds at level 0 , 10 and $20 \%$ in diets of growing male Zaraibi goats. Generally, the economic efficiency was improved by $24.07 \%$ with two Sesame seeds rations (G2 and G3), compared with G1 (control).

Table (7): Economic efficiency of Zaraibi kids fed different experimental rations.

\begin{tabular}{lccc}
\hline Item & G1 & G2 & G3 \\
\hline Daily body gain, g & 65.00 & 76.67 & 72.62 \\
Daily feed intake (g/h) as fed: & & & 318 \\
From CFM & 444 & 381 & 100.85 \\
From SS & -- & 50.48 & 897 \\
From CS & 903 & 898 & 1.2615 \\
Cost of consumed feed, (L.E./h) & 1.4031 & 1.3318 & 2.54 \\
Price of weight gain, (L.E./h) & 2.27 & 2.68 & 17.37 \\
Feed cost/kg gain, (L.E.) & 21.59 & 17.37 & 2.01 \\
Feed economic efficiency, $\%$ & 1.62 & 2.01 & \\
\hline
\end{tabular}

The prevailing prices, per ton, at time of the study are, CFM 2550 L.E., CS 300 L.E. and 1 ton SS 1800 L.E. while,1 kg live BW of kids was 35 L.E.

\section{CONCLUSION}

It could be concluded that using Sesame seedsunsuitable for manufacturing at level of 10 (G2) and (G3) $20 \%$ had a positive effect on improving daily body gain of growing Zaraibi kids and the improvement was better with the low level (reached to 17.95 in G2 vs. $11.72 \%$ in G3). Moreover, feed utilization and economic efficiency were noticeable better with two tested groups (G2 and G3) without any adverse effects on metabolic parameters (rumen and blood). Further studies are however needed to evaluate the utilization of such new by-products at higher levels by some other farm animals during different physiological stages and management conditions.

\section{REFERENCES}

A.O.A.C. (1995). Official Methods of Analysis (16th Edit). Association of Official Analytical Chemists, Washington, D.C., USA.

Ahmed (2003). The Economic marketing weight of male Zaraibi goats. Egyptian J. Nutrition and Feeds, 6 ( special Issue) : 1311.

Ahmed M.E., E.I. Shehata, M.E. El-Kholany, G.I. ElEmam, E.I. Khalifa and H. Bahery (2013). Productive performance of Zaraibi goats fed berseem and/or triticale silage. The $4^{\text {th }}$ Scientific Conference of Animal Production Research Institute, P: 184.

Ahmed, M. E. (1999). Improving feed conversion efficiency during reproduction-stress-phases. Ph.D. Thesis, Fac. Agric., Mansoura Univ.
Ahmed, M. E. and M.E. El-Kholany (2012). Productive performance, some rumen parameters and blood profile of Zaraibi goats fed rations supplemented with chufa tubers during late pregnancy and suckling periods. J. Animal and Poultry Prod., Mansoura Univ., Vol. 3 (12): 537.

Ahmed, M. E., E.I. Shehata, F.F. AbouAmmou, Khalifa, E. I. and O.A. EL- Zolaky (2009). Productive and reproductive performance of Rahmani sheep fed rations containing reed forage (Arundodomax, L.) either fresh, hay or silage. Egyptian J. Sheep and Goat Sci., 4(1) 45.

Ahmed, M.E., E.I. Shehata and A.M. Abdelhamid (2000). Growth performance of male kids according to different feeding levels, concentrate to roughage ratio and diet inclusion of bentonite. Proc. $3^{\text {rd }}$ all Africa Conf. Anim. Agric. \& $11^{\text {th }}$ Conf. Egyptian Soc. Anim. Prod., Alexandria, 69 November, p: 201.

Amr, A. Gabr, Ayman A. Al-Mwafy and Mohamed E. Ahmed (2014). Influence of clays addition in the ration containing berseem hay naturally contaminated with aflatoxin on Zaraibi goats' males performance. Asian J. of Anim. And Vet. Advances. 9 (12): 756.

Beckstrom - Sternberg, S.M. and J.A. Duke (1994). The Phytochemical database. http:/genome.cornell.edu/cgibin/WebAce/Webac $\mathrm{e} ? \mathrm{db}=$ phytochemdb.

Conway, E.F.(1957). Micro diffusion Analysis and Volumetric Error. Rev. Ed. Lock Wood, London.

Dipasa, (2003). Sesame honey bits. www. dipasa.nl/ seshobit. htm. 
El-Kholany, M. E., E. S. Soliman, F. A. El-Sayed and M. E. Ahmed (2013). Growth performance, some rumen parameters and blood profile of male Zaraibi goats fed diets containing Sesbania Sesban seeds as a new source of protein. J. Agric. Sci. Mansoura Univ. vol. 4:(12) 747.

El-Saidy D. M. S. Deyab, S. H. Mahmoud, M. A. AlGarhy and Hayam D. Tonsy (2009).Nutrition evaluation of sesame seed meal, Sesamum indicum (L.) as alternative protein source in diets of juvenile mono sex male Nile tilapia (Oreochromis niloticus). Egypt. J. Aquat. Biol. \& Fish. Vol. 13 (1) 1110.

El-Sayed, F. A. and W.M.A. Sadek (2015). Effect of feeding different types of silage (berseem or kochia and their mixture with fodder beet) on growth performance of growing male goats. J. Animal and Poultry Prod., Mansoura Univ., Vol. 6: (8): 567.

Gabr, A.A.; M.E. Ahmed; Fathia A. Ibrahim and M.S. Seleem (2015). Growth performance, some rumen parameters and blood profile of male Zaraibi goats fed diets added with Chufa tubers (Cyprus Esculentus L.) during the growing period. J. Agric. Sci. Mansoura Univ. vol. 6:(9) 609.

Ibrahim, F.A., Soliman, E.S, A. A. Abd El-Hamid and M. E. Ahmed (2012). Growth performance and feed utilization efficiency of Rahmani lambs fed some legume and /or grass silages. Egyptian J. of Sheep and Goats Sciences, 7 (2): 1.

Kaneko, K., K. Yamasaki, Y. Tagawa, M. Tokunaga, M. Tobisa and M. Furuse, (2002). Effects of dietary sesame meal on growth, meat ingredient and lipid accumulation in broilers. Jpn. Poult. Sci., (39): 56.

Kaneko. I.H. (1989). Chemical Biochemistry of Animals. $4^{\text {th }}$ ED. Academic Press, Inc USA.

Lee, S.C., S.M. Jeong, S.Y. Kim, K.C. Nam and D.U. Ahn (2005). Effect of far-infrared irradiation on the antioxidant activity of defatted sesame meal extracts. J. Agric. Food Chem., (53): 1495.

Mamputu, M. and R.J. Buhr (1995). Effect of substituting sesame meal for soybean meal on layer and broiler performance. Poult. Sci., (74): 672.

Mehrez, A. Z.; A. A. Gabr; A. A. Mahrous; O. A. Zelaky and Amal M. A. Fayed (2013). Influence of live yeast feed additives on productive performance of growing rahmany lambs. J.Animal and Poultry Prod., Mansoura Univ., Vol.4 (5): 233.

Mohamed, A. I. and M. Rangappa (1992). Screening soybean ( grain and vegetable) geno type for nutrients and anti nutritional factors. Plant Foods for Human Nutrition. (42):87.
NRC (1981).Nutrient Requirements of Domestic Animals. Nutrient Requirements of Goats. National Research Council, Washington, D.C. USA, of Official Analytical Chemists, Washington, D.C., USA.

Nzikou, J.M.; L. Matos; G. Bouanga-Kalou, C.B. Ndangui; N.P.G. Pambou-Tobi; A. Kimbonguila; Th. Silou; M. Linder and S. Desobry (2009). Chemical composition on the seeds and oil of Sesame (Sesamum indicum L.) grown in GongoBrazzaville. J. of food Dci. And Technology. 1 (1): 6 .

Pugalenthi, M. V. Vadivel, P. Gurumoorthi and K. Janardhanan (2004). Comparative nutritional evaluation of little known legumes, Tamarindus indica, Erythrima indica and Sesbania bispinosa. Tropical and Sub tropical Agroecosy tems. (4) : 107.

Ram, R., D. Catlin, J. Romero, and C. Cowley (1990). Sesame: New approaches for crop improvement. In:J. Janick and J.E. Simon (Eds.), Advances in New Crops. Timber Press, Portland, OR, pp: 225.

Sadek, W.M.A. (2011). Nutritional requirements of rahmani ewes. Ph.D. Thesis, Fac. Agric., Mansoura Univ.

SAS Institute (2003). SAS/STATR User's Guide: statistics. Ver. 9.1, SAS Institute Inc., Cary, NC, USA.

Shultz, T.A. and E. Shultz (1970). Estimation of rumen microbial nitrogen by three analytical methods. J. Dairy Sci , pp: 53.

Soliman, A. A., M. E. Ahmed, Faten. F. Abou Ammou, E. I. Shehata, M. K. Abou Elmaged, S. A. Tawfik and M. A. Shebl ( 2010). Impact of some feed additives on Zaraibi goats performance and blood profile fed aflatoxins contaminated diets. American- Eurasian J. Agric. And Erviron Sci., 7 (1) : 80 .

Soliman, E.S, A.E.M. Kinizy, Bahira K. Mohamed and M. El-H. Haggag (1997). Studies on using sesbania and Teosinte forage in feeding of growing Zaraibi goats Egypt. J. Appl. Sci.,12 (5) $: 36$.

Tawfik, S.A, M.E. Ahmed, E.I. Shehata and O.B. ELGazzar (2005). Effect of adding chamomile flowers to aflatoxins contaminated diet on growth performance, rumen parameters and some blood components of growing lamb's .4th Int. Sci. Conf., Mansoura. Pp: 251.

Warner, A.C.I. (1964). Production of volatile fatty acids in the rumen, methods of measurements. Nutr. Abst. \& Rev., (34): 339.

Yanez, E, Zacarias, I, Aguayo, M, Vasquez, M. and E. Guzman (1995). Nurtitive value evaluated on rats of new cultivars of common beans ( Phaseolus vulgaris) relased on Chile. Plant foods for human nutrition. (47) : 301. 
الأداء الإتتاجى وكفـاءة تحويل الغذاء وصورة الدم فى ذكور المـاعز الزرايبى المغذاة على علائق تحتوى بذور

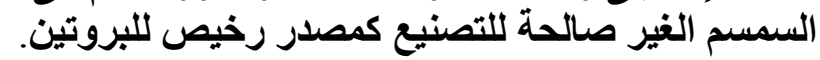

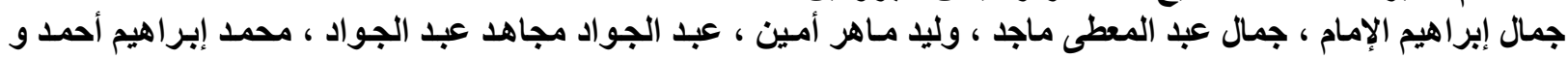

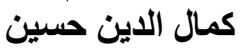
معهد بحوث الإنتاج الحيو اني - مركز البحوث الزراعية _دقي - جيزة.

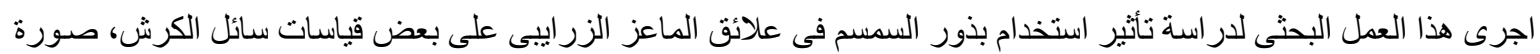

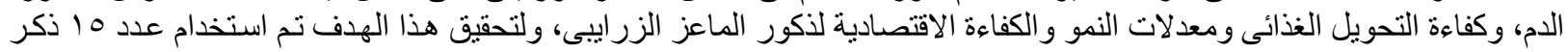

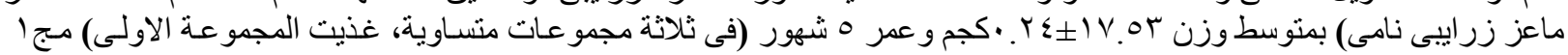

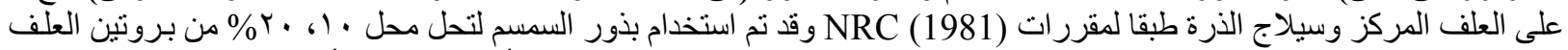

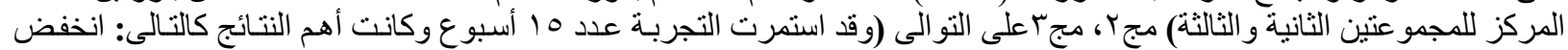

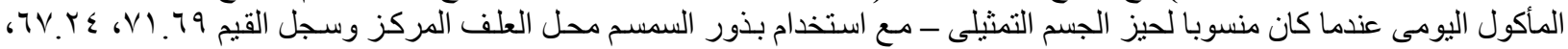

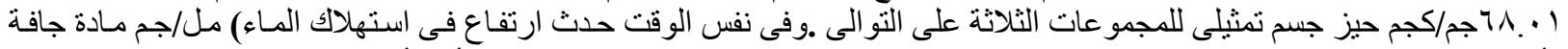

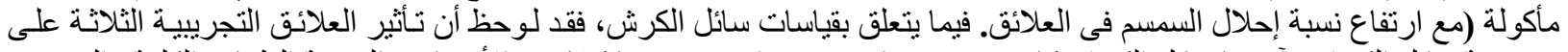

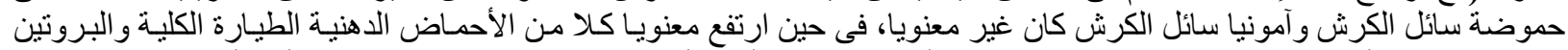

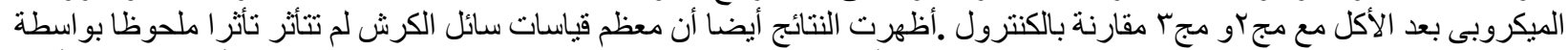

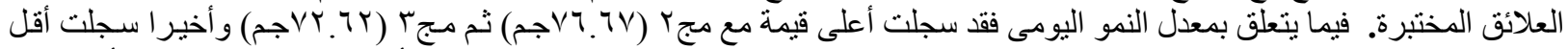

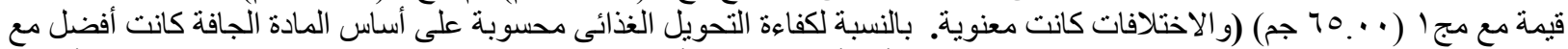

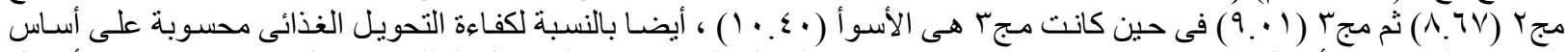

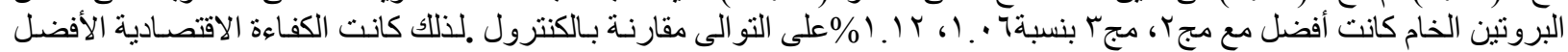

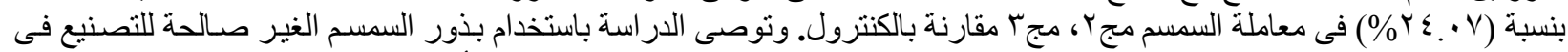

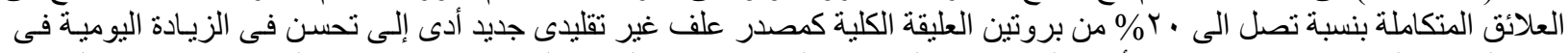

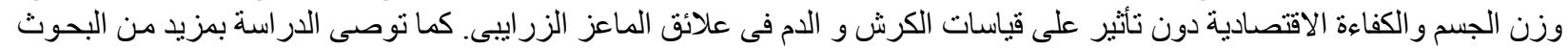

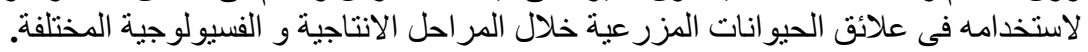

